\title{
KEYNES, J.-B. SAY, J. S. MILL, AND SAY'S LAW: A NOTE ON KATES, GRIEVE, AND AHIAKPOR
}

\author{
BY \\ ALAIN BÉRAUD AND GUY NUMA
}

\section{INTRODUCTION}

John Maynard Keynes rarely mentions Jean-Baptiste Say in the General Theory. ${ }^{1}$ His discussion of classical political economy essentially rests on John Stuart Mill's views. However, in the preface of the French edition of the General Theory, Keynes ([1939] 1973, p. xxxv) believed he could not address a French audience without bringing up Say. He criticizes Say's loi des débouchés (law of outlets) on three points. He takes issue with the Frenchman for arguing that "demand is created by supply," and for assuming that "the economic system was always operating up to its full capacity." Say's framework, Keynes concludes, "is clearly incompetent to tackle the problems of unemployment and of the trade cycle."

This note aims to shed some light on the heated debate involving James Ahiakpor, Roy Grieve, and Steven Kates on Keynes's interpretation of Mill's views of Say's Law. In a nutshell, Grieve argues that Keynes correctly restated Mill's thesis, whereas Ahiakpor and Kates disagree with Grieve's position. We first assess the arguments used by Keynes to attack the classical theory and find his criticisms of Say and Mill to be ill-founded. Second, we examine the crucial question of whether Keynes was right when he excoriated the essential "substance" of Say's thesis. In doing so, we discuss how to interpret Say's law of outlets. Finally, we examine Mill's fourth proposition on capital. Although this concept does not exist in the form given by Mill in Say's writings, Say developed a similar idea when he compared the effects of unproductive and productive consumption.

\section{KEYNES'S CRITICISM}

Keynes ([1939] 1973, p. xxxv) argues that, for Say, "demand is created by supply." In fact, Say's formulation was different. For Say ([1814] 2006, p. 250), "a product is

\footnotetext{
Alain Béraud, THEMA, University of Cergy-Pontoise, France; Guy Numa, Economics Department and Honors College, University of Massachusetts Boston, USA. Email: guy.numa@umb.edu.

${ }^{1}$ Say is mentioned in three instances in chapter 2, chapter 3, and chapter 23, respectively.
} 
no sooner created than it opens, from that instant, an outlet for other products to the full extent of its own value." Say suggested that the creation of a good opened up the potential for something to be demanded, but such good did not necessarily create the demand because it was not necessarily sold. The difference resides in the fact that Say referred to the potential of demand while Keynes implied the automatic creation of demand. This point allows us to clarify an all-too-common confusion between Walras's Law and Say's Law. Walras's Law is derived from aggregating individual budget constraints, which implies that the total value of demand is equal to the total value of supply. When an individual determines the quantity of goods to be supplied and demanded based on a given vector of prices, the individual assumes that he will be able to acquire the goods at these prices: selling what he supplies and buying what he demands. In contrast, Say reasoned in terms of equality between the value of the individual's resources and the value of his expenditure, which is radically different (more on that below).

Keynes ([1939] 1973, p. xxxv) alleges that "Say was implicitly assuming that the economic system was always operating up to its full capacity." Nothing could be further from the truth. In his Lettres à Malthus, Say refuted David Ricardo's claim that "there is always as much industry as capital employed, and that all saved capital is always employed" (Say 1820, p. 101n1). Drawing upon the experience of the 1813 recession in France, Say contended that many savings were not invested, not all capital was employed, and many workers were jobless. In other words, contrary to what Keynes said, for Say, the economy was not always operating up to its full capacity.

Keynes ([1939] 1973, p. xxxv) concludes that Say's framework "is clearly incompetent to tackle the problems of unemployment and of the trade cycle." It is true that the concept of "unemployment" is not analyzed in Say's writings. In the French language of the nineteenth century, the term chomage ("unemployment") did not have the same meaning as today. It was used to designate work interruption during holidays. Say was perfectly aware that some individuals could not find employment, but he did not offer any theoretical explanation. It is also true that Say did not formally analyze business cycles, but he did analyze economic crises. For him, crises resulted from an imbalance between supply and demand. Say later developed a monetary theory of crises, which put the blame on the banking system. In his discussion of the 1825 crisis in England, he explained that banks discounted too many bills of exchange and overissued banknotes. Their clients panicked and tried to redeem their assets in cash, forcing banks to interrupt their discounting operations. Merchants could no longer obtain financing, businesses went bankrupt, and the situation escalated into a general crisis. Though Say did not clearly explain the recovery process - and thus failed to thoroughly analyze business cycles - he nonetheless offered a penetrating interpretation of the causes of economic crises, which differed from Mill's.

\section{WHAT IS SAY'S LAW OF OUTLETS?}

To answer this question, let us first turn to Kates (present volume, hereinafter 2018, p. 281), who suggests that "Say's Law states recessions are never caused by ... demand deficiency." He (2018, p. 279) even corrects Ahiakpor, his anti-Keynesian ally. Kates, however, is wrong. In fact, his misleading definition has previously been exposed (Jonsson 1999, p. 968). In Kates's vernacular, "Say’s Law” means just what he wants it to mean. 
In the nineteenth century, the common message of Say's Law's defenders was that production was the source of demand. It was not that supply was necessarily equal to demand or that demand deficiency could not cause crises. This latter issue is merely a corollary of Say's Law (Cowen 1982). Like Say, one could fundamentally defend Say's Law while not embracing Say's corollary as irrefutable.

Say's thesis was that "there is no bound that can be ascribed to productions that originate from the industry and the capital of a country" (Say [1828-29] 2010, p. 356). Say described a sequential model with consecutive, not simultaneous, transactions. An individual started off by selling his productive services (which included labor) or the goods that he produced. He then used the proceeds of the sale to purchase other products. Indeed, in between the two transactions, his money holdings could be greater or less than his initial holdings. Say's reasoning can be summarized as follows: the total value of resources - his initial money holdings plus the proceeds of the sale-was equal to the total value of expenditure, which included his final money holdings.

It should be noted that when Say used the term "product," he always meant its value. A product was not only something that met our needs; it was something whose utility was worth what it cost. Simply put, the value of the product was not a physical quantity, but an exchange value that was nothing other than its market price. In Say's mind, an unsold good did not constitute a product. If some products were oversupplied, they would be sold for less than their production cost. The purchasing power of the producer would be reduced, and this loss would eventually affect his expenditure.

Thus, if some products did not sell, it was because "many people bought less because they earned less" (Say [1814] 2006, p. 253). Demand was constrained by successful sales (Béraud and Numa, present volume, hereinafter 2018). Say thus recognized that the failure to produce (or the failure of factor owners to sell their services) must have repercussions on the demand for output, because the demand for product was financed out of earned income. Literally, this means that demand deficiency was possible and could lead to economic crises. It could be argued that a glut could occur only in the short run, but it would still be a general glut (Hollander 2005a, pp. 214-219; 2005b, p. 384).

For Say, if individuals wish to increase their money holdings, money demand might exceed money supply. In this case, one of two scenarios will take place. If money is lacking, monetary substitutes such as bills of exchange will be used. If the excess demand for money still persists, the value of money will rise. In an open economy in which money is convertible into gold at a fixed rate, an inflow of gold will lead to an increase in the quantity of money, as David Hume described. This process does not operate flawlessly, however, and Say clearly understood that changes in the value of money affected the real economy.

In Cours, Say ([1828-29] 2010, p. 479) studied the effects of a growing quantity of money. He noted that more money stimulated all sales and thereby boosted the demand for goods for two reasons: final prices outran production costs, giving larger profits to producers; and inflation expectations led consumers to spend money more rapidly. Say thus admitted that some costs became sticky—particularly money wages; but, unlike Malthus and Keynes, he did not argue that money wages displayed downward rigidity. As noted by previous commentators, there is a clear difference on this issue between Keynes and classical economists like Say and Mill. 


\section{PRODUCTIVE AND UNPRODUCTIVE CONSUMPTION}

Mill ([1848] 1965, pp. 78-79) argued that "demand for commodities is not demand for labour," and "that to purchase produce is not to employ labour." Say and Ricardo excepted, Mill pointed out, very few economists supported this idea. This remark is problematic, as Say ([1828-29] 2010, p. 735) actually defended a different position. He wrote that "the demand for labor depends upon ... consumers' demand for the produce of labor." However, from a policy standpoint, he seemed more inclined to share Mill's views when he dealt with the effects of consumption. Say distinguished between two types of consumption: reproductive consumption replaced with greater values than those values that it destroyed; while unproductive consumption, whose only purpose was to satisfy our needs, destroyed values without replacing them. Both had identical immediate effects, but the former allowed capital reproduction and accumulation while the latter did nothing to enhance national wealth. There was, thus, no reason to promote it. Stimulating a form of consumption that destroyed products that later had to be replaced made no sense (Say [1826] 2006, p. 881n1). Thus, Say clearly opposed Malthus's views, but did he oppose Keynes's? To cope with recessions, Say would have probably opted for stimulating investment, not consumption.

\section{CONCLUSION}

Keynes clearly misinterpreted Say. It is no wonder, then, that Keynesian economists such as Grieve (2016, p. 347) subsequently misinterpreted Say's law of outlets. In fact, both Say and J. S. Mill admitted that individuals could increase or decrease their money holdings in normal economic conditions. Thus, the supply of goods (money excepted) did not constitute demand. However, Kates, a so-called defender of "Say's Law," has fallen into the same trap: distorting the core message of Say and his allies to better frame his own anti-Keynesian rhetoric.

Keynes's analysis differs from Say's and Mill's on three points. First, Keynes explicitly analyzes unemployment, which was not Say's and Mill's main focus. This analytical difference can be explained by a difference of approach. While in the nineteenth century the issue was poverty, in the twentieth century unemployment became the main concern. Second, Keynes stands out with his assumption of downward rigidity of money wages. This was not the focal point of Say's and Mill's analyses. Finally, Keynes's contribution is a macroeconomic model that formalizes markets interaction under a condition of money-wage stickiness.

\section{REFERENCES}

Béraud, Alain, and Guy Numa. 2018. "Beyond Say's Law. The Significance of J.-B. Say's Monetary Views." Journal of the History of Economic Thought 40 (2): 217-241.

Cowen, Tyler. 1982. "Say's Law and Keynesian Economics." In Richard H. Fink, ed., Supply-side Economics: A Critical Appraisal. Frederick: University Publications of America, pp. 160-184.

Grieve, Roy H. 2016. “Keynes, Mill, and Say's Law: The Legitimate Case Keynes Didn't Make against J. S. Mill." Journal of the History of Economic Thought 38 (3): 329-349. 
Hollander, Samuel. 2005a. Jean-Baptiste Say and the Classical Canon in Economics. The British Connection in French Classicism. London and New York: Routledge.

2005b. “Two Hundred Years of Say's Law: Essays on Economic Theory's Most Controversial Principle ed. by S. Kates.” History of Political Economy 37 (2): 382-385.

Jonsson, Petur. 1999. “Say's Law and the Keynesian Revolution: How Macroeconomics Lost Its Way by Steven Kates.” Southern Economic Journal 65 (4): 967-970.

Kates, Steven. 2018. "Making Sense of Classical Theory." Journal of the History of Economic Thought 40 (2): 279-283.

Keynes, John Maynard. [1939] 1973. “Preface to the French edition.” In J. M. Keynes, The General Theory of Employment, Interest and Money. London: Macmillan. Reprint in The Collected Writings of John Maynard Keynes. Volume VII. London: Macmillan, Cambridge University Press, pp. xxxi-Xxxv.

Mill, John Stuart. [1848] 1965. Principles of Political Economy: With Some of Their Applications to Social Philosophy. In John Stuart Mill, Collected Works of John Stuart Mill. Edited by J. M. Robson. Volumes II and III. Toronto: University of Toronto Press.

Say, Jean-Baptiste. [1803, 1814, 1817, 1819, 1826, 1841] 2006. Traité d'économie politique ou simple exposition de la manière dont se forment, se distribuent et se consomment les richesses. Édition variorum in CEuvres Complètes de Jean-Baptiste Say. Paris: Economica.

- 1820. Lettres à M. Malthus sur différents sujets d'économie politique notamment sur les causes de la stagnation générale du commerce. Paris: Londres Bossange.

. [1828-29] 2010. Cours complet d'économie politique pratique. Paris: Rapilly. Édition variorum in Euvres Complètes de Jean-Baptiste Say. Paris: Economica. 